\title{
Obsessive-compulsive disorder and Tourette Syndrome: is there a relationship?
}

\begin{abstract}
The authors describe the main characteristics of Obsessive-Compulsive Disorder, the fourth most frequent psychiatric disease, and Tourette Syndrome. Considered completely separate disorders, there is growing scientific evidence that there is a connection between them. The authors present clinical, genetic and neuroimaging data reinforcing this idea, and call attention to the importance of research in this area, as they believe that the definition of more homogenous subgroups will facilitate the identification of biological markers and predictors of treatment response.
\end{abstract}

$\mathrm{O}$ bsessive-Compulsive Disorder (OCD) has a lifetime prevalence of three percent in the general population and is now considered as the fourth most frequent psychiatric disease. OCD is diagnosed based on the patient's clinical history and its essential features, include recurrent obsessions and/or compulsions.

According to the newest classification of the American Psychiatric Association, the DSM-IV,' obsessions are persistent ideas, thoughts, impulses, or images that are experienced as intrusive and inappropriate. Fear of contamination is the most frequent obsession, followed by repeated doubts, and a need to have things in a particular order or symmetry. These repetitive and unwanted thoughts are time consuming (at least one hour a day) and cause distress or significant impairment.

Compulsions are repetitive behaviors (e.g. hand washing, checking, ordering) or mental acts (e.g. praying,

\section{Address for correspondence: \\ Maria Conceição do Rosário}

Alameda Lorena, 846 - Ap. 12

São Paulo/SP - Brasil - CEP 01424-001 counting, repeating words silently). They are usually performed in order to prevent or reduce anxiety or distress, caused most of the time by an obsession.

Tourette Syndrome (TS) is characterized by multiple motor tics and one or more vocal tics, with onset in childhood and a waxing and waning course. Tics are sudden, repetitive, involuntary, stereotyped movements or vocalizations. They are classified according to their complexity as simple (involving a single muscle) or complex (involving multiple muscle groups), and to their duration and frequency as transient (lasting at least two weeks but less than 12 months) or chronic (lasting more than a year). ${ }^{2}$

For a long time considered completely separate disorders, recent clinical, genetic and neuroimaging studies have suggested that there is a relationship between OCD and TS. Clinical studies have demonstrated a higher incidence of tics and TS in OCD patients when compared to the general population. Likewise, patients with TS also have an increased rate of obsessive-compulsive symptoms and $\mathrm{OCD}$ when compared to a normal control group. ${ }^{3}$ Furthermore, family genetic studies developed by the Yale 
Child Study Center have shown that first-degree relatives of TS patients have a higher prevalence of TS, chronic motor tics, and OCD than do normal controls. ${ }^{3}$

As for neuroimaging, studies with OCD and TS patients have pointed to an abnormal function of multiple parallel segregated corticostriatal circuits in the basal ganglia. Studies with MRI in TS patients have yielded data consistent with an alteration on the normal asymmetry ( $\mathrm{L}$ $>\mathrm{R}$ ) of the lenticular nucleus (putamen and globus pallidus), probably secondary to alterations of the putamen. The normal asymmetry of the caudate nucleus and its volume are also altered in OCD patients. These findings reinforce Baxter's theory suggesting that there is an OCDTS spectrum, with the putamen being more affected in TS and the caudate in OCD. ${ }^{2}$

Based on the studies described above, OCD is heterogeneous, with some forms related to TS. Thus, the knowledge of an association between OCD and TS is important for future research in the pathophysiology of these two disorders. By defining homogenous subgroups, we may contribute to the identification of biological markers and predictors of prognosis and treatment response, helping clinicians to develop more effective management strategies.

\section{RESUMO}

Os autores descrevem as características principais do Transtorno Obsessivo-Compulsivo, o quarto diagnóstico psiquiátrico mais frequente atualmente, é a Síndrome de Tourette. Considerados como doenças completamente distintas, existem evidências científicas de que há uma ligação entre elas. Os autores fornecem alguns estudos clínicos, genéticos e de neuroimagem que reforçam essa idéia e apontam a importância de pesquisas nessa área, já que eles acreditam que a definiçāo de subgrupos mais homogêneos vai propiciar a identificação de marcadores biológicos e fatores preditivos de resposta ao tratamento.

\section{REFERENCES}

1. American Psychiatric Association. Diagnostic and Statistical Manual of Mental Disorders, Fourth Edition. Washington, DC: American Psychiatric Association, 1994.

2. Coffey BJ, Miguel EC, Savage CR, Rauch SL. Tourette's disorder and related problems: A review and update. Harvard Review Psych 1994;35:615-747.
3. Leckman JF, Pauls DL, Peterson BS, Riddle MA, Anderson GM, Cohen DJ. Pathogenesis of Tourette syndrome: Clues from the clinical phenotype and natural history. Adv Neurol 1992;58:15-24.

4. Singer H, Reiss A, Brown J, et al. Volumetric MRI changes in basal ganglia of children with Tourette Syndrome. Neurol 1993;43:950-6. 